\title{
Stem anatomy of annual legume intercropping components: white lupin (Lupinus albus L.), narbonne (Vicia narbonensis L.) and common (Vicia sativa L.) vetches
}

\author{
Lana Zorić ${ }^{1}$, Aleksandar Mikić ${ }^{2}$ Svetlana Antanasović ${ }^{3}$, Dunja Karanović ${ }^{1}$, Branko Ćupina ${ }^{3}$, Jadranka Luković ${ }^{1}$ \\ ${ }^{1}$ University of Novi Sad, Faculty of Sciences, Department of Biology and Ecology, Trg D. Obradovica 2, 21000 Novi Sad, Serbia \\ ${ }^{2}$ Institute of Field and Vegetable Crops, Maksima Gorkog 30, 21000 Novi Sad, Serbia \\ ${ }^{3}$ University of Novi Sad, Faculty of Agriculture, Trg D. Obradovica 8, 21000 Novi Sad, Serbia \\ email: lana.zoric@dbe.uns.ac.rs
}

\begin{abstract}
The effect of intercropping on stem anatomy of both supporting (Lupinus albus) and supported (Vicia narbonnensis and $V$. sativa) annual forage legumes was investigated using stereological method. Intercropped plants showed minimal differences in volume densities $(V v)$ of stem tissues and forage chemical composition compared to sole crops. The proportions of lignin and NDF (Neutral Detergent Fiber) positively correlated with xylem $V v$. The proportions of ADF (Acid Detergent Fiber), cellulose and ash in intercropped plants were increased or decreased mostly by less than $10 \%$ compared to those in pure stands. The Anatomical Equivalent Ratio (AER) defined as the ratio based on anatomical quality-determining parameters, can assist in the evaluation of the benefits of specific intercropping systems. Intercropping of the legume species studied in this work, especially L. albus with V. sativa, showed encouraging results from anatomical perspective since it would not cause a decline of forage quality.
\end{abstract}

Key words: legume-legume intercropping, forage quality, ADF, NDF, legume stem anatomy, Anatomical Equivalent Ratio

\section{Introduction}

In comparison to sole crop systems, intercropping has shown many advantages such as more efficient utilization of natural resources, higher forage and grain yields, higher stress tolerance, or lower demand for fertilizers and pesticides (Andersen et al. 2007). Legume species are often included in intercropping systems, mostly due to their nitrogen fixing ability, that improves soil fertility, and high crude protein content in both forage and grain dry matter leading to improved product quality (Hauggaard-Nielsen et al. 2011). There have been numerous and thorough analyses of below- and aboveground aspects of traditional intercropping systems such as those of grain legumes with cereals (Bedoussac and Justes 2010a, b), annual legumes with brassicas (Cortés-Mora et al. 2010) and perennial forage legumes with grasses (Annicchiarico et al. 2014).

Recent studies recommended mutual intercropping of legume species; one suggests the use of an annual legume, e.g. pea (Pisum sativum L.), in establishing perennial forage legume, most often red clover (Trifolium pratense L.), alfalfa (Medicago sativa L.) and sainfoin (Onobrychis viciifolia Scop.). The annual both plays the role of a bioherbicide at the early stages of growth and development of the perennials and contributes to the total forage yield and quality of its first cut (Ćupina et al. 2011). The other scheme suggests mutual intercropping of annual legumes, where one component supports another resulting in decreased biotic stress, increased photosynthetic potential and eventually higher forage and grain yields (Mikić et al. 2012). The forage production in such intercrops, where, for instance faba bean (Vicia faba L.) or white lupin (Lupinus albus L.) support peas or common vetch (Vicia sativa L.), usually results in high crude protein content in forage dry matter, better nitrogen dynamic in the agroecosystem, and elimination of fertilizer and/or herbicide application. In this way, mutual legume intercropping proves not only an economically reliable, but also a highly environment-friendly system of crop production (Mikić et al. 2013). Supporting crops, such as grass pea (Lathyrus sativus L.), peas or vetches fight the weeds in supported crops, sown usually at a wider space, while the supporting crops, such as white lupin or faba bean mechanically support the former and thus contribute to preserving photosynthetically active leaves, increasing the leaf proportion to the total forage dry matter yield and improve its quality. (Mikić et al. 2012).

Environmental factors, such as temperature, water deficit, solar radiation or soil nutrients, greatly influence forage dry matter quality by inducing modifications in plant development, changing its chemical composition or altering the leaf/stem ratio (Buxton 1996). Intercropping induces microenvironmental changes in plant growth conditions. 
The examination of different aspects of its effect on plant biology and biological response to such specific growing conditions is of a particular importance for predicting forage dry matter quality. Anatomical parameters are among those that play a significant role in the determination of forage quality, mainly digestibility, thus should be one of the main targets in the evaluation of intercropped forages (Krstić et al. 2008).

The data on structural characteristics of intercropped legume species are currently limited. Previous anatomical investigations of alfalfa established with pea showed no significant effect on alfalfa lamina anatomical characteristics, photosynthetic tissue, proportion of different tissues or size of the cells (Zorić et al. 2012). Some heliomorphic lamina parameters were more prominent in sole crops and lower density stands. Soybeans (Glycine max (L.) Merr.) intercropped with sorghum (Sorghum bicolor (L.) Moench.) exhibited slower morphological development, and contained less forage dry matter. In addition, their stem digestibility was higher and neutral detergent fiber (NDF) concentration lower compared to sole stands. The leaf parameters did not differ significantly between intercropped and sole crops of soybean (Redfearn et al. 1999).

Stem structure is an important determinant of legume forage digestibility (Jung and Engels 2002, Guines et al. 2003), which decreases with maturation mostly due to the increased concentration of indigestible cell walls and lignin. Non-lignified stem tissues such as chlorenchyma, collenchyma, cambium, phloem and pith parenchyma, remain completely degradable at all stages of stem development whilst lignified xylem, phloem fibers and xylem fibers are less degradable or fully resistant to degradation (Moore and Jung 2001, Jung and Engels 2002). Therefore, reduced proportion of lignified tissues could improve total digestibility of forage legumes. As xylem is the most lignified legume stem tissue with the greatest contribution to the total amount of lignin, its proportion or volume density should be carefully monitored and reduced during the attempts to improve forage quality (Guines et al. 2003, Krstić et al. 2008, Zorić et al. 2014). While NDF is used as an estimate of cell-wall concentration and acid detergent fiber (ADF) serves as a predictor of forage digestible energy, both are negatively correlated with digestibility (Buxton 1996). The reduction of alfalfa stem degradability is a result of the deposition of lignin in xylem tissue. It was found to be negatively correlated with NDF and cell wall concentration, and positively with pectin and cellulose concentration (Jung and Lamb 2006). Positive correlations were reported for alfalfa between the proportion of xylem and lignin and cellulose concentrations as well as between the proportion of pith parenchyma and pectin concentration (Gronwald and Bucciarelli 2013). In addition to lignin concentration, digestibility is also limited by its distribution as well as the microorganism accessibility limitations arising from the presence of non-disrupted, lignified cell walls (Jung et al. 2000, Guines et al. 2003).

Complex study of intercropping systems demands a spotted research on the impact of intercropping on forage quality parameters. In this work, we focused on the effect of intercropping on the stem anatomical parameters of both supporting and supported cool season annual forage legumes. Since stem is the organ that affects digestibility most significantly, we analyzed its structure in supporting and supported legumes grown as sole crops in comparison to their mutual intercrops. The aim of this research was to evaluate and compare stem anatomical responses of legume-legume intercropping components, to establish a relationship between the structural characteristics and chemical composition of intercropped and sole crop plants, as well as to evaluate the potential effects of intercropping on forage digestibility.

\section{Material and methods}

In 2012 and 2013 a small-plot field trial was carried out at the Experimental Field of the Institute of Field and Vegetable Crops at Rimski Šančevi ( $45^{\circ} 20^{\prime} \mathrm{N}$ and $\left.19^{\circ} 51^{\prime} \mathrm{E}, 84 \mathrm{~m} \mathrm{ASL}\right)$, in the vicinity of Novi Sad, Serbia. Mean temperatures and precipitations are presented in Table 1. It included three cool season annual legume crops, namely white lupin, narbonne vetch and common vetch (autumn- and spring-sown) (Table 2). According to the major principles of intercropping annual legumes with each other for forage production (Ćupina et al. 2011), white lupin played the role of a supporting crop, due to its excellent standing ability, while the vetches were supported crops, being highly lodging susceptible. Autumn sowing was performed on October 2012, while the spring on April 2013. The plot size was $5 \mathrm{~m}^{2}$ with three replications. In the intercrops, the seeds of both components were sown at a double-reduced density as compared to the one in their sole crops and mixed within the rows in order to provide a uniform distribution of both. 
Table 1. Temperatures and precipitations for hydrological year 2012/2013 at Rimski Šančevi

\begin{tabular}{lcccccccccccccc}
\hline \multicolumn{1}{c}{ Parameter } & \multicolumn{11}{c}{ Months } \\
\hline & $\mathrm{X}$ & $\mathrm{XI}$ & $\mathrm{XII}$ & $\mathrm{I}$ & $\mathrm{II}$ & $\mathrm{III}$ & $\mathrm{IV}$ & $\mathrm{V}$ & $\mathrm{VI}$ & $\mathrm{VII}$ & VIII & IX & Avg \\
Temperature $\left({ }^{\circ} \mathrm{C}\right)$ & 12.7 & 9.1 & 0.3 & 2.3 & 3.6 & 5.4 & 13.4 & 17.4 & 20.2 & 22.3 & 22.9 & 15.7 & 12.1 \\
LTA $\left({ }^{\circ} \mathrm{C}\right)^{*}$ & 11.6 & 6.2 & 1.4 & -0.3 & 1.6 & 6.3 & 11.7 & 17.0 & 20.0 & 21.7 & 21.2 & 16.9 & 11.3 \\
Precipitation $(\mathrm{mm})$ & 51.4 & 35.3 & 56.3 & 60.5 & 47.2 & 73.0 & 35.8 & 118.1 & 125.7 & 34.1 & 26.7 & 107.8 & 64.3 \\
LTA $(\mathrm{mm})$ & 46.0 & 51.5 & 46.2 & 37.0 & 32.5 & 38.9 & 47.2 & 59.8 & 87.5 & 67.2 & 69.1 & 47.0 & 52.5 \\
\hline
\end{tabular}

*Long term average (LTA)

Table 2. Species, varieties and seed amount used in the experiment

\begin{tabular}{lccc}
\hline Species & Variety & \multicolumn{2}{c}{ Seed amount $\left(\mathrm{g} \mathrm{m}^{-2}\right)$} \\
\hline & & Sole crop & Intercrop \\
White lupin & Vesna & 40 & 20 \\
Narbonne vetch & Landrace-Local collection & 30 & 15 \\
Common vetch-autumn sown & Neoplanta & 16 & 8 \\
Common vetch-spring sown & Novi Beograd & 16 & 8 \\
\hline
\end{tabular}

The plants in each treatment group were collected at the end of the flowering period at the end of May 2013. All anatomical analyses were conducted in five replications. Plant stems were sampled from the middle parts of the plots, avoiding marginal plants, and fixed in 50\% ethanol, after which cross-sections were obtained using Leica CM 1850 cryostat, at temperature of $-20{ }^{\circ} \mathrm{C}$, at cutting intervals of $40 \mu \mathrm{m}$. Five sections per stem were made along the stem axis at sampling points selected according to the systematic uniform random sampling principle (Fig. 1) (Kubinova 1993). The interval ( $T$ ) between the consecutive segments was $7-17 \mathrm{~cm}$, determined in reference to the stem height. The $z$ position of the first section was randomly selected within the $0-7(17) \mathrm{cm}$ interval and the segments were numbered incrementally starting from the top of the stem.

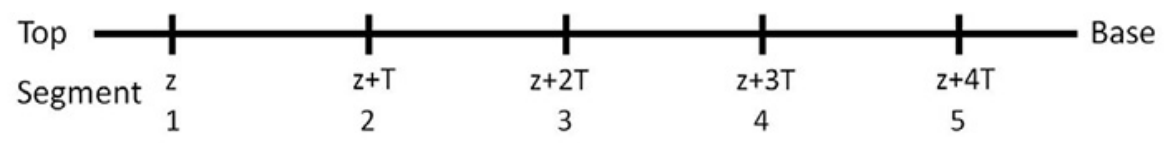

Fig. 1. Schematic representation of the systematic uniform random sampling process applied to the stem segments

The obtained sections were stained for lignin using acid phloroglucinol test (Jones et al. 2003). Light microscopy and stereological measurements were performed using Image Analyzing System Motic Images Plus. The proportion of tissues was estimated by point-counting method, using the point grid test system consisting of 588 test points (5000 - 8000 per stem). Volume densities $(V v(x))$ of different tissues were calculated using the formula given by Kubinova (1993):

$$
V v(x)=\frac{\sum_{j=1}^{n} P j(x)}{\sum_{j=1}^{n} P j(y)}
$$

where $n$ is the number of examined sections, $\operatorname{Pj}(x)(j=1, \ldots, n)$ number of test points located within the specific tissue on $j$-number of sections, and $\operatorname{Pj}(y)(j=1, \ldots, n)$ is the number of test points within the entire stem cross-section on $j$-number of sections.

Chemical analyses included measuring of NDF, ADF, lignin, protein, fat, cellulose and ash content. NDF and ADF were determined by ANKOM Technology (2000), Methods 12 - 13, while others were determined according to the methods described in the Association of Official Analytical Chemists (AOAC) techniques 2000 (Horwitz 2000). Forage samples amounting to $500 \mathrm{~g}$ of green forage were taken from each plot from $0.2 \mathrm{~m}^{2}$ of sampled area and dried in a drying oven at $60{ }^{\circ} \mathrm{C}$ for $72 \mathrm{~h}$. The dried samples were ground to pass through a $1 \mathrm{~mm}$ sieve size for analyzing their nutritive values.

Data were statistically processed using STATISTICA for Windows v. 10.0., whereby the means, coefficients of variation (CVs) and correlation coefficients were calculated. The significance of differences in measured parameters was determined using Duncan's test $(p \leq 0.05)$. 


\section{Results \\ Distribution of lignified tissues}

In the analyzed legume species the strongest lignification of cell walls was recorded in xylem followed by sclerenchyma fibers. In more mature stem segments, pith parenchyma cells in central part of the stem ruptured and formed a cavity, whilst in Vicia species those in perimedullar zone lignified. The primary walls of epidermis and collenchyma cells underwent extensive thickening but did not show positive reaction with phloroglucinol. Phloem, cortex and cylinder parenchyma cells were thin-walled with primary walls not containing lignin.

\section{Morphological, anatomical and chemical properties of pure crops}

Among the species, autumn-sown $V$. sativa had the highest stems of small cross-section area whilst the shortest stems with significantly the greatest cross-section were recorded in V. narbonensis (Table 3). Based on CVs, sample variability was low for stem height but was significantly higher for stem cross-section area. The highest $V v$ of mechanical tissue and xylem were obtained in L. albus. As these tissues were composed of cells with thick, and mostly lignified cell walls, it was not surprising that this species had the highest proportion of NDF, ADF, lignin and cellulose in dry matter (Table 4). White lupin also had the lowest $V v$ of cortex parenchyma, which resulted in the lowest proportion of proteins in dry matter.

Table 3. Means and comparisons of stem morphological parameters and volume densities $(\mathrm{Vv})$ of stem tissues of legume forage species grown as sole crops. CVs values (\%) are given in parenthesis.

\begin{tabular}{lcccc}
\hline & L. albus & V. narbonensis & $\begin{array}{c}\text { V. sativa } \\
\text { (spring-sown) }\end{array}$ & $\begin{array}{c}\text { V. sativa } \\
\text { (autumn-sown) }\end{array}$ \\
\hline Stem height $(\mathrm{cm})$ & $44.8(5.9)^{\mathrm{c}^{*}}$ & $36.7(11.4)^{\mathrm{c}}$ & $64.5(12.7)^{\mathrm{b}}$ & $101.0(15.7)^{\mathrm{a}}$ \\
Stem cross-section area $\left(\mathrm{mm}^{2}\right)$ & $9.7(45.9)^{\mathrm{b}}$ & $12.7(20.6)^{\mathrm{a}}$ & $6.6(38.7)^{\mathrm{c}}$ & $7.4(28.0)^{\mathrm{c}}$ \\
$V_{v}$ epidermis & $2.5(44.4)^{\mathrm{bc}}$ & $3.2(34.2)^{\mathrm{a}}$ & $2.3(36.8)^{\mathrm{c}}$ & $2.9(26.9)^{\mathrm{ab}}$ \\
$V_{v}$ collenchyma & $7.0(39.0)^{\mathrm{a}}$ & $4.0(32.6)^{\mathrm{b}}$ & $2.7(42.4)^{\mathrm{c}}$ & $2.1(32.5)^{\mathrm{c}}$ \\
$V_{v}$ cortex parenchyma & $17.4(31.6)^{\mathrm{c}}$ & $20.3(8.6)^{\mathrm{b}}$ & $24.8(13.1)^{\mathrm{a}}$ & $18.5(13.0)^{\mathrm{bc}}$ \\
$V_{v}$ sclerenchyma & $4.1(24.4)^{\mathrm{a}}$ & $2.7(23.9)^{\mathrm{b}}$ & $3.7(47.5)^{\mathrm{a}}$ & $4.0(18.2)^{\mathrm{a}}$ \\
$V_{v}$ phloem & $8.2(20.5)^{\mathrm{b}}$ & $8.0(34.5)^{\mathrm{b}}$ & $7.1(37.5)^{\mathrm{b}}$ & $11.4(21.0)^{\mathrm{a}}$ \\
$V_{v}$ xylem & $28.0(37.6)^{\mathrm{a}}$ & $23.7(55.1)^{\mathrm{a}}$ & $12.3(37.4)^{\mathrm{b}}$ & $15.8(27.7)^{\mathrm{b}}$ \\
$V_{v}$ cylinder parenchyma & $28.1(15.5)^{\mathrm{a}}$ & $26.3(38.1)^{\mathrm{a}}$ & $30.4(15.6)^{\mathrm{a}}$ & $28.0(25.7)^{\mathrm{a}}$ \\
$V_{v}$ of lignified tissues & $32.1(33.8)^{\mathrm{a}}$ & $26.4(50.0)^{\mathrm{b}}$ & $16.0(38.7)^{\mathrm{c}}$ & $20.0(23.0)^{\mathrm{c}}$ \\
\hline
\end{tabular}

*The difference between the values with the same letter was not statistically significant at $p \leq 0.05$, according to Duncan's test

Common vetch ( $V$. sativa) had significantly the lowest $V v$ of xylem, and the highest $V v$ of cylinder and cortex parenchyma (spring-sown specimens), and phloem (autumn-sown specimens) (Table 3 ). This induced lower proportions of lignin in dry matter, compared to the other two species, as well as the lowest proportions of NDF in spring-sown specimens (Table 4). Narbonne vetch ( $V$. narbonensis) stood out as the species with high $V v$ of $x y l e m$ and moderate proportions of thin-walled tissues. Due to such a percentage of tissues the proportion of lignin was high, but not of NDF, ADF, cellulose or proteins, which had moderate or low values compared to the other species. Volume densities of all examined tissues showed high level of variability within each species. The lowest CVs values were obtained for cortex parenchyma. 
Table 4. Chemical composition of the forage dry matter (DM \%) of aboveground plant biomass

\begin{tabular}{|c|c|c|c|c|}
\hline & L. albus & V. narbonensis & $\begin{array}{c}\text { V. sativa } \\
\text { (spring-sown) }\end{array}$ & $\begin{array}{c}\text { V. sativa } \\
\text { (autumn-sown) }\end{array}$ \\
\hline Neutral detergent fibers (NDF) & $48.52^{a}$ & $43.08^{b}$ & $40.91^{c}$ & $43.76^{b}$ \\
\hline Acid detergent fibers (ADF) & $41.69^{a}$ & $36.97^{c}$ & $38.41^{b}$ & $38.92^{b}$ \\
\hline Lignin & $10.48^{a}$ & $9.55^{\mathrm{ab}}$ & $8.83^{b c}$ & $8.12^{c}$ \\
\hline Protein & $12.71^{\mathrm{c}}$ & $24.62^{b}$ & $27.76^{\mathrm{a}}$ & $23.71^{b}$ \\
\hline Fat & $1.34^{\mathrm{a}}$ & $1.36^{\mathrm{a}}$ & $0.88^{a}$ & $1.17^{\mathrm{a}}$ \\
\hline Cellulose & $33.14^{\mathrm{a}}$ & $29.26^{c}$ & $28.67^{c}$ & $31.62^{b}$ \\
\hline Ash & $12.53^{\mathrm{b}}$ & $12.87^{b}$ & $14.26^{\mathrm{a}}$ & $10.37^{c}$ \\
\hline
\end{tabular}

\section{The effect of intercropping on morphology, anatomy and chemical properties}

In white lupin (L. albus), intercropping resulted in a significant increase of biomass production. Stems of this species became significantly taller and thicker in both cropping combinations (Fig. 2). This outcome could not be attributed to the increased proportion of a single tissue. The proportions of epidermis and collenchyma significantly decreased in both intercropped white lupins, whilst proportions of cortex parenchyma and phloem were significantly higher only in plants grown with $V$. sativa (Fig. 3a, 4). Intercropping induced an increase in the protein content in the aboveground biomass, which was accompanied by lower proportions of lignin and ash (Fig. 5a).

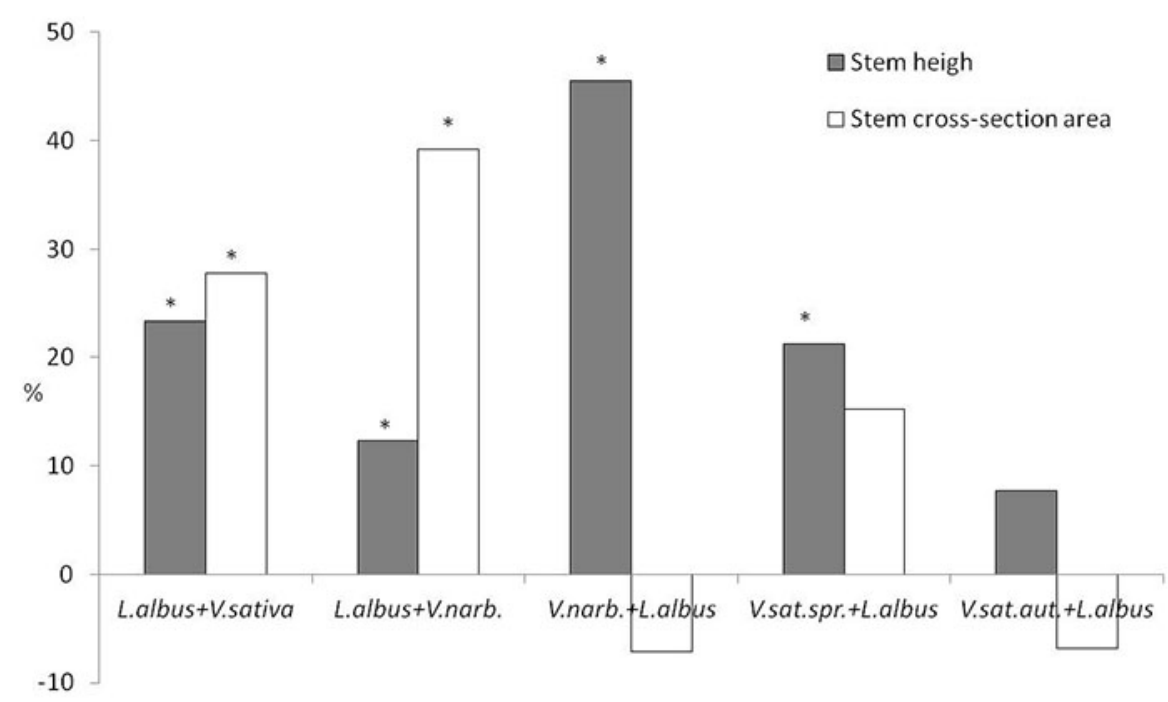

Fig. 2. The effect of intercropping on stem morphological parameters of legume forages, expressed as a percentage of the values obtained for the control plants, grown as a pure crops

In Vicia species, while the stems of intercropped plants were significantly more elongated, their cross-section area did not alter significantly. Stems morphology was unaffected by intercropping in the autumn-sown plants (Fig. 2). $V$. narbonensis was characterized by the most stable proportions of stem tissues, with an exception of cortex parenchyma $V v$, which significantly increased in intercropped plants (Fig. 3b, 6a,b). In $V$. sativa, $V v$ of cortex parenchyma significantly decreased whilst that of phloem increased in the intercropped plants (Fig. 3b, 6c,d). In the autumn-sown plants, a significant increase in $V v$ of sclerenchyma and xylem, and a decrease in $V v$ of cylinder parenchyma were recorded (Fig. 3b, 6e,f).

These structural differences between intercropped Vicia plants and those grown as sole stands were accompanied by minor changes in the percentage of their chemical constituents (Fig. 5a,b). Most of the values obtained for the intercropped plants differed by up to $10 \%$ compared to the controls. The highest differences were recorded in intercropped autumn-sown common vetch, where the values obtained for lignin proportion increased by about $15 \%$, whilst protein proportion decreased by about $18 \%$. 

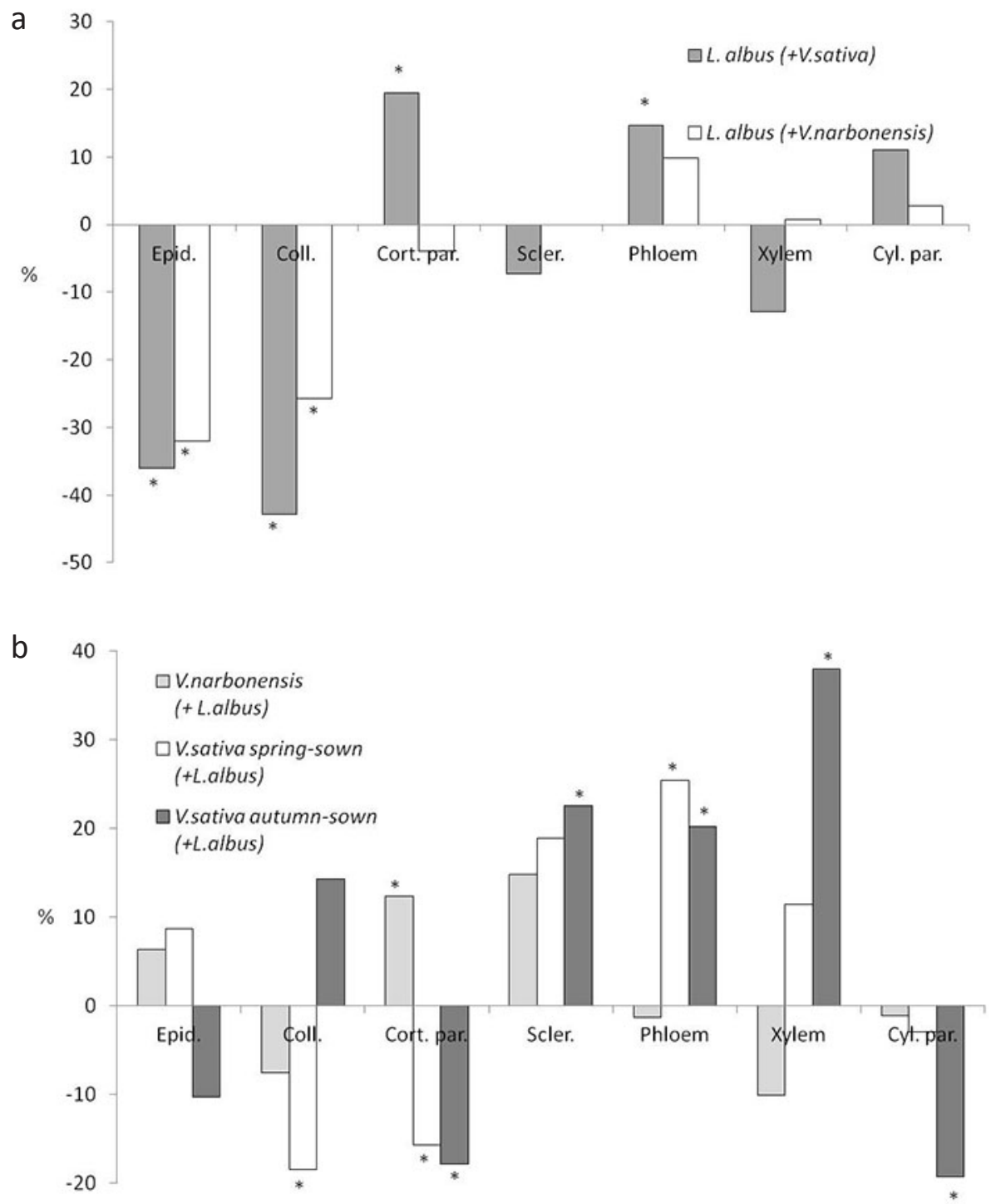

Fig. 3. Volume densities of stem tissues of intercropped plants, expressed as a percentage of the values obtained for the control plants, grown as sole stands: (a) L. albus; (b) V. narbonensis, V. sativa springsown and $V$. sativa autumn-sown 

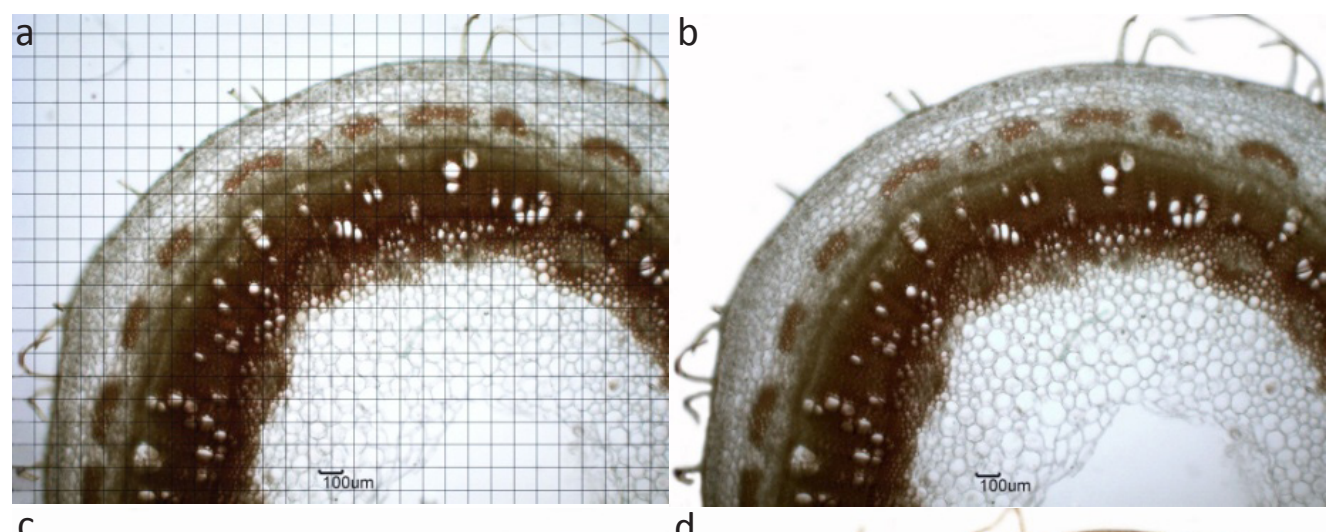

C

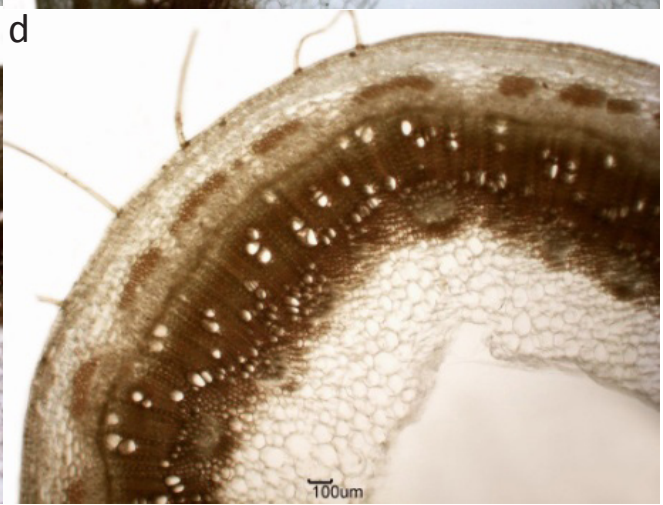

Fig. 4. Cross-sections of $L$. albus middle stem segments: (a) Cross-section of $L$. albus stem with superimposed point grid test system consisting of 588 test points; (b) L. albus grown as sole stand; L. albus intercropped with (c) V. sativa and (d) V. narbonensis

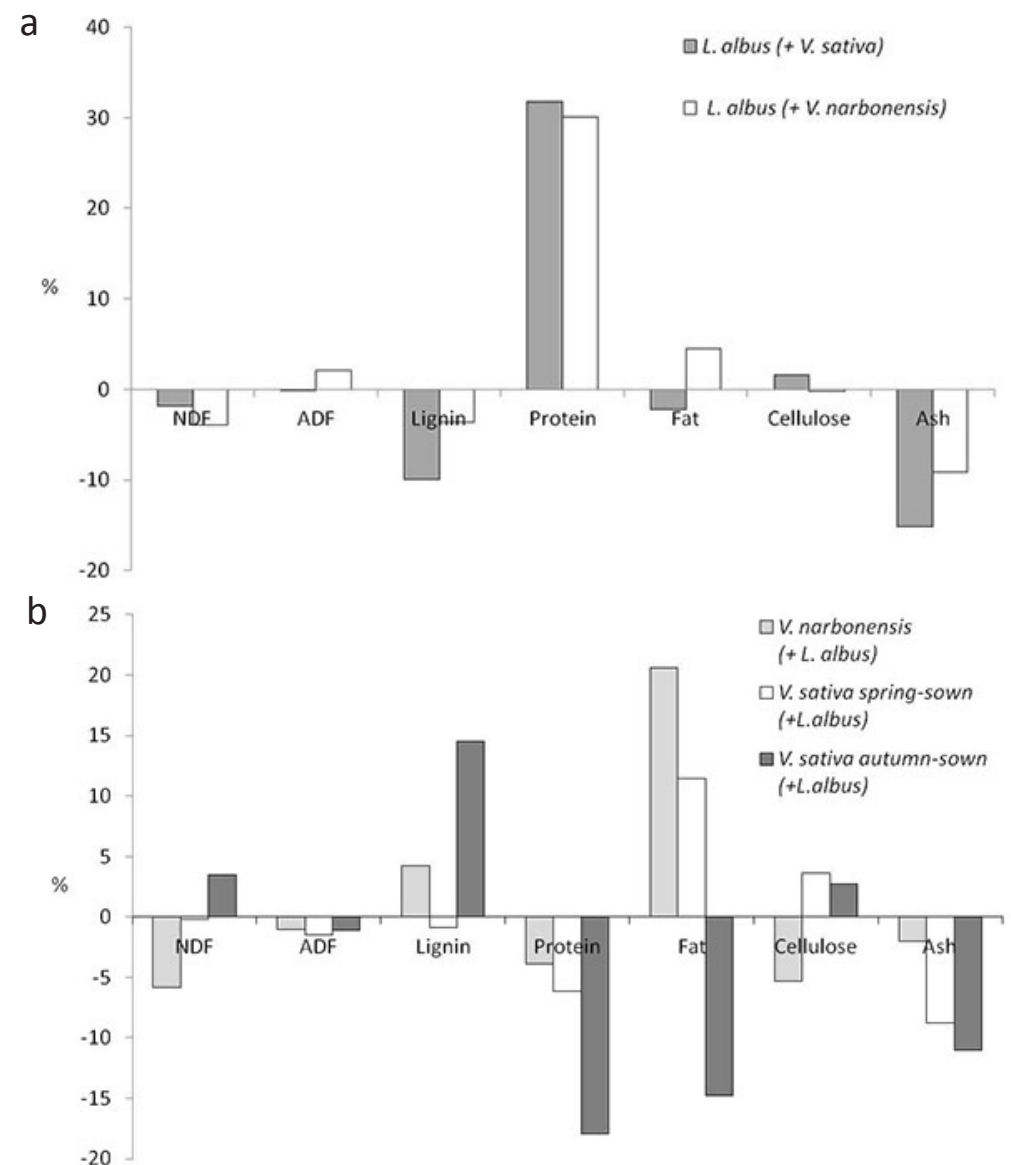

Fig. 5. Chemical composition of aboveground parts of intercropped plants expressed as a percentage of the values obtained for the control plants grown as sole stands. (a) L. albus; (b) V. narbonensis, V. sativa spring-sown and $V$. sativa autumn-sown 


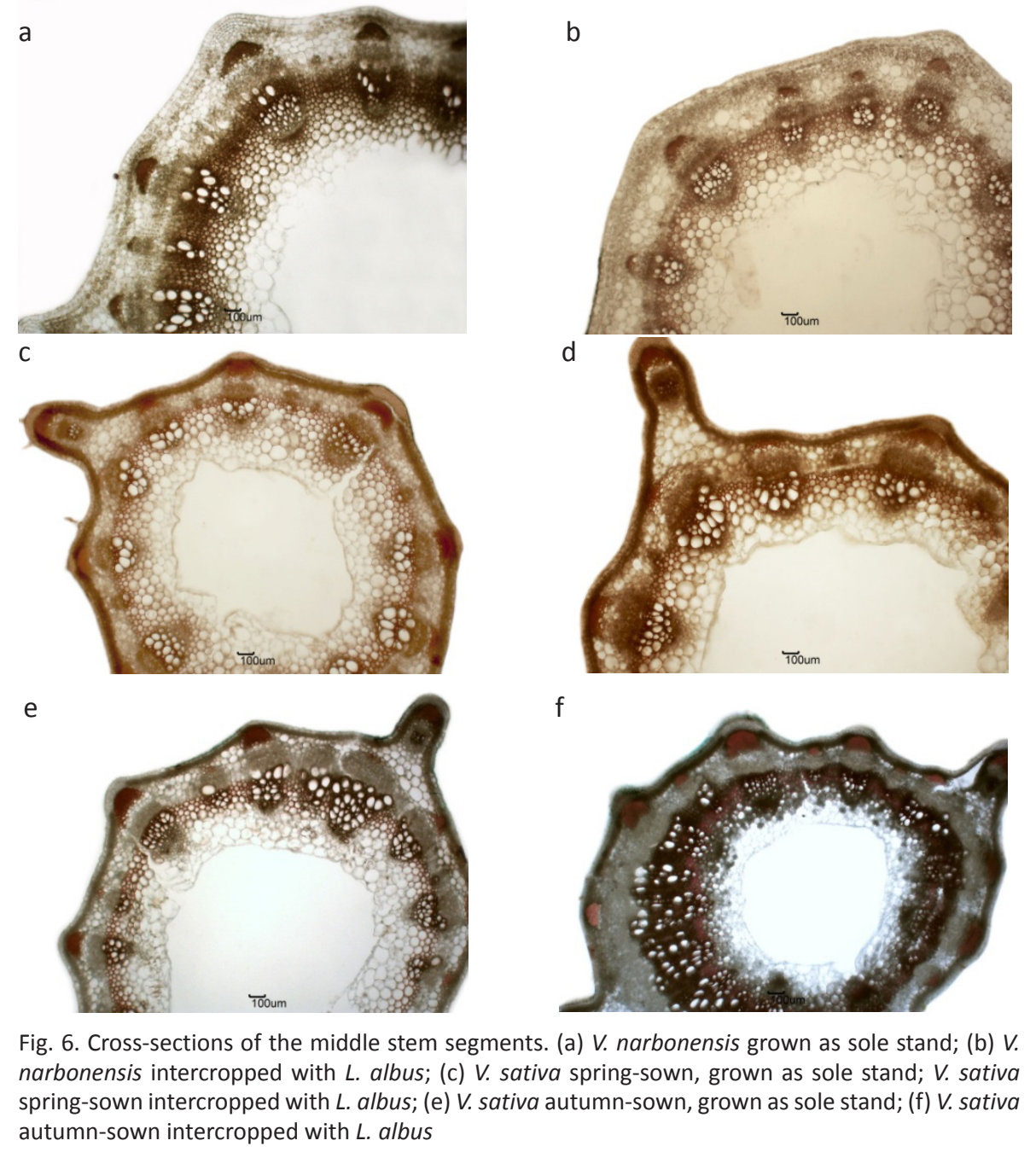

\section{Correlations of anatomical and chemical parameters}

The $V v$ values pertaining to xylem, collenchyma and cortex parenchyma showed the most significant correlations with stem chemical composition (only statistically significant correlations were further commented). As the xylem proportion increased, so did NDF $(r=0.78)$, lignin $(r=0.85)$ and fat $(r=0.68)$, whilst the proportion of proteins decreased $(r=-0.86)$. In contrast, an increase in the cortex parenchyma $V v$ resulted in lower percentage of $\operatorname{NDF}(r=-0.68)$ and cellulose $(r=-0.74)$. Although collenchyma was not subsumed into lignified tissues, its $V v$ was positively correlated with the proportions of lignin $(r=0.88)$, while its correlation with the protein proportion was negative $(r=-0.78)$. Epidermis was significantly negatively correlated with ADF $(r=-0.83)$ and cellulose $(r=-0.68)$, whilst sclerenchyma, phloem and cylinder parenchyma $V v$ did not significantly affect the total percentage of chemical constituents.

\section{Anatomical Equivalent Ratio (AER)}

In legume forages, low proportion of lignified tissues is a favorable anatomical characteristic. Therefore, in order to assess the forage quality of intercropped legumes, based on anatomical parameters, we suggest the introduction of a parameter, conditionally referred to as Anatomical Equivalent Ratio (AER), and calculated as follows:

$$
A E R=\frac{\sum V v \text { of thick-walled tissues of intercropped plants }}{\sum V v \text { of thick-walled tissues of monocropped plants }}
$$

whereby an AER value below 1 would justify intercropping. 
According to the obtained AER values for the examined legume species, the positive effect of intercropping was recorded in $V$. narbonensis (Table 5 ). The values obtained for xylem $V v$ of intercropped plants were lower by $10 \%$ compared to the control plants. Although the differences between intercropped and monocropped plants in the $V v$ of lignified tissues were not statistically significant, as their sum was lower in intercropped narbon vetch, it resulted in $A E R<1$. The positive result was also obtained for white lupins; however, it applied only to those grown in combination with common vetch, where $V v$ of non-lignified tissues significantly increased.

Table 5. Anatomical Equivalent Ratio (AER) values of intercropped legume species, based on volume densities of lignified tissues

$\begin{array}{cccc} & \text { L. albus }+ & \text { V. narbonensis }+ & \text { V. sativa (ss) + } \\ \text { V. sativa } & \text { V. narbonensis } & \text { L. albus } & \text { L. albus }\end{array}$

\title{
Discussion
}

\author{
Morphological, anatomical and chemical properties of pure crops
}

As intercropped plants develop, they compete for different resources, light in particular (Redfearn et al. 1999). Supported crops mostly develop in the shade of the supporting crop. Shaded shoots show a variety of morphogenic changes and actively adjust their morphology and physiology to the canopy environment (Ballaré et al. 1997). Plants grown in dense canopies tend to be taller. Shading by neighboring plants can induce stem elongation, mostly by increasing internode length and the number of nodes (Collins and Wein 2000). Plant and stem height has been reported to be strongly and negatively correlated with digestibility in alfalfa due to the decrease in the leaf/stem ratio (Julier and Huyghe 1997). The legumes tested in our study, with the exception of autumn-sown $V$. sativa, had significantly taller stems when intercropped with other legume species, which could be attributed to more shaded growing conditions. This was not desirable for $L$. albus quality, since it was previously reported that dwarf genotypes were more stabile, with better lodging resistance and better partitioning of assimilates to pods and seeds (Huyhge 1997). However, concurrently intercropped white lupin had significantly (about 30-40\%) thicker stems, which is not a common characteristic of shaded plants, and could thus contribute to stability and lodging resistance of this species. More specifically, intercropping increased the total biomass production of white lupin. As, in general, the proportions of different tissues did not change significantly, this morphological modification should not have a negative effect on digestibility.

Volume densities and distribution of lignified tissues, particularly in the stem, are important anatomical parameters linked to forage digestibility (Krstić et al. 2008, Zorić et al. 2011). Among the species grown in monoculture, $V$. sativa could be singled out due to its most favorable ratio of lignified to non-lignified stem tissues. This distribution of tissues was followed by a favorable proportion of chemical constituents, low proportion of lignin and high proportion of proteins. On the other hand, L. albus had the highest proportion of lignified stem tissues, followed by high concentration of lignin, ADF, NDF and cellulose and low protein concentration. As these parameters adversely affect quality, they caused $L$. albus to be ranked the lowest among the legumes tested.

\section{The effect of intercropping on morphology, anatomy and chemical properties}

Although the effect of limited sunlight on lignification and digestibility is not always consistent, shaded plants tend to have less lignified tissues. However, this characteristic is related to their delayed development rather than changes in lignification patterns (Moore and Jung 2001). In general, our findings reveal that mutual intercropping of legume species did not significantly affect anatomical features of the forages. A comparison of the anatomical parameters pertaining to the intercropped and control plants revealed insignificant differences in $V_{v}$ of stem tissues. On the other hand, cortex parenchyma and phloem $V v$ in white lupin stems intercropped with common vetch increased significantly. In addition, an increase in the protein content in the aboveground biomass, as well as lower proportions of lignin and ash could be observed. However, as the stems of the intercropped white lupins were also higher and thicker, they sustained a greater number of leaves, which could have contributed to the observed increase in protein concentration. Intercropped common vetch had significantly lower proportions of cortex parenchyma tissue and higher proportions of phloem. In the autumn-sown vetch, an increase in $V v$ of sclerenchyma and xylem was also recorded, resulting in a greater proportion of lignin. Intercropped narbon vetch was characterized by the higher proportion of cortex parenchyma. 
The proportions of lignin, NDF, ADF, cellulose and ash in intercropped plants differed mostly by less than $10 \%$ compared to those in control plants. Proportions of NDF and lignin were strongly and positively correlated with xylem $V v$. The cell walls of xylem vascular elements are secondary thickened and strongly lignified, which explains such correlations. Although expected, correlations of cylinder parenchyma and chemical constituents were not statistically significant, mostly because of the desintegration of central cells and lignification of peripheral cells in older stem segments. The formation of central cavity begins at the first stem segment in Vicia species, and in second or even third segment in L. albus. Sclerenchymatous parenchyma in perimedullar zone of central cylinder could be observed from the second stem segment in both Vicia species. Gronwald and Bucciarelli (2013) found that differences in tissue proportions contributed to differences in cell wall concentration and composition in alfalfa. In line with this observation, the greater development of xylem noted in our study was consistent with higher concentrations of lignin and cellulose.

Sclerenchyma fibers also have secondary cell walls but sclerenchyma $V v$ was not significantly correlated with the aforementioned parameters. The total contribution of sclerenchyma in the analyzed stems was generally low ranging from 2 to $4 \%$. Moreover, primary sclerenchyma fibers were not necessarily lignified; xylem was the only lignified tissue in the first stem segment. The lignification of sclerenchyma mostly began from the second stem segment. Therefore, although rationally expected, significant correlation between percentage of lignin and $V v$ of sclerenchyma fibers was not found.

\section{Anatomical Equivalent Ratio (AER)}

We defined the Anatomical Equivalent Ratio (AER) as the parameter that described the relationship between $V v$ of lignified tissues in intercropped plants and those grown in sole crop. This parameter could support the evaluation of the benefits of specific intercropping systems based on anatomical quality-determining parameters. The sum of $V v$ of lignified tissues was lower in intercropped narbon vetch, and in white lupins intercropped with common vetch. Also AER < 1 was obtained in these species only. Considering the minimal structural changes noted in these species, we conclude that, from an anatomical perspective, they exhibited positive respond to intercropping.

Among the tested legume-legume intercrops, L. albus with spring-sown $V$. sativa was the anatomically most succesful one. This combination was especially favorable with respect to the improvement in the white lupin characteristics resulting in a total AER value of 0.88 . In accordance with Mikić et al. (2012), the benefits obtained for common vetch were less significant, and the measured parameters did not differ significantly from those in the controls. Among the tested species the white lupin-common vetch combination was fully compatible, showing the most positive response to all the basic intercropping principles.

\section{Conclusion}

In conclusion, legume-legume intercropping did not cause a forage quality decline. Since forage quality is defined by anatomical, as well as morphological, physiological, genetic and biochemical parameters, different aspects of these species should be further studied. Intercropping of the legumes tested in the present work showed to be encouraging from an anatomical perspective, and thus it could impact forage legume growing and quality.

\section{Acknowledgements}

This work was financially supported by the Ministry of Education, Science and Technological Development, Republic of Serbia, Grant No. 31024.

\section{References}

ANKOM Technology 2000. Analytical procedures. Manual Online. Cited 17 November 2014. Updated 11 April 2014. https://ankom.com/analytical-procedures.aspx.

Andersen, M.K., Hauggaard-Nielsen, H., Weiner, J. \& Jensen, E. S. 2007. Competitive dynamics in two- and three-component intercrops. Journal of Applied Ecology 44: 545-551.

Annicchiarico, P., Julier, B., Louarn, G. \& Maamouri, A. 2014. Alfalfa intercropping and competitive ability. Legume Perspectives 4: 29-30.

Ballaré, C.L., Scopel, A.L. \& Sanchez, R.A. 1997. Foraging for light: photosensory ecology and agricultural implications. Plant, Cell and Environment 20: 820-825.

Bedoussac, L. \& Justes, E. 2010a. The efficiency of a durum wheat - winter pea intercrop to improve yield and wheat grain protein concentration depends on N availability during early growth. Plant and Soil 330: 19-35.

Bedoussac, L. \& Justes, E. 2010b. Dynamic analysis of competition and complementarity for light and N use to understand the yield and the protein content of a durum wheat - winter pea intercrop. Plant and Soil 330: 37-54. 
Buxton, D.R. 1996. Quality-related characteristics of forages as influenced by plant environment and agronomic factors. Animal Feed Science and Technology 59: 37-49.

Collins, B. \& Wein, G. 2000. Stem elongation response to neighbour shade in sprawling and upright Polygonum species. Annals of Botany 86: 739-744.

Cortés-Mora, F.A., Piva, G., Jamont, M. \& Fustec, J. 2010. Niche separation and nitrogen transfer in Brassica-legume intercrops. Field and Vegetable Crops Research 47: 581-586.

Ćupina, B., Mikić, A., Stoddard, F., Krstić, Đ., Justes, E., Bedoussac, L., Fustec, J. \& Pejić, B. 2011. Mutual legume intercropping for forage production in temperaste regions. In: Lichtfouse, E. (ed.). Genetics, Biofuels and Local Farming Systems, Sustainable Agriculture Reviews 7. Dordrecht, Heidelberg, London, New York: Springer Science+Business Media. p. 347-365.

Gronwald, J. W. \& Bucciarelli, B. 2013. Comparison of stem morphology and anatomy of two alfalfa clonal lines exhibiting divergent cell wall composition. Journal of the Science of Food and Agriculture 93: 2858-2863.

Guines, F., Julier, B., Ecalle, C. \& Huyghe, C. 2003. Among and within-cultivar variability for histological traits of lucerne (Medicago sativa L.) stem. Euphytica 130: 293-301.

Hauggaard-Nielsen, H., Peoples, M.B. \& Jensen, E.S. 2011. Faba bean in cropping systems. Grain Legumes 56: 32-33.

Horwitz, W. 2000. Official Methods of Analysis. 17th ed. Gaithersburg, MD: USA. Association of Official Analytical Chemists. 2200 p. Huyghe, C. 1997. White lupin (Lupinus albus L.). Field Crops Research 53: 147-160.

Jones, A., Reed, R. \& Weyers, J. 2003. Practical Skills in Biology. $3^{\text {rd }}$ ed. Edinburgh, United Kingdom: Pearson Education Limited. 468 p. Julier, B. \& Huyghe, C. 1997. Effect of growth and genotype on alfalfa digestibility in a multilocal trial. Agronomie 17: 481-489.

Jung, H.G. \& Engels, F.M. 2002. Alfalfa stem tissues: cell wall deposition, composition and degradability. Crop Science 42: 524-534.

Jung, H.J., Jorgensen, M.A., Linn, J.G. \& Engels, F.M. 2000. Impact of accessibility and chemical composition on cell wall polysaccharide degradability of maize and lucerne stems. Journal of the Science of Food and Agriculture 80: 419-427.

Jung, H.G. \& Lamb, J.F.S. 2006. Stem morphological and cell wall traits associated with divergent in vitro neutral detergent fiber digestibility in alfalfa clones. Crop Science 46: 2054-2061.

Krstić, L., Merkulov, L., Luković, J. \& Boža, P. 2008. Histological components of Trifolium L. species related to digestive quality of forage. Euphytica 160: 277-286.

Kubinova, L. 1993. Recent stereological methods for the measurement of leaf anatomical characteristics: estimation of volume density, volume and surface area. Journal of Experimental Botany 44: 165-173.

Mikić, A., Ćupina, B., Mihailović, V., Krstić, Đ., Đorđević, V., Perić, V., Srebrić, M., Antanasović, S., Marjanović-Jeromela, A. \& Kobiljski, B. 2012. Forage legume intercropping in temperate regions: models and ideotypes. In: Lichtfouse, E. (ed.). Genetics, Biofuels and Local Farming Systems, Sustainable Agriculture Reviews 11. Dordrecht, Heidelberg, London, New York: Springer Science+Business Media. p. 161-182.

Mikić, A., Ćupina, B., Mihailović, V., Krstić, Đ., Antanasović, S., Zorić, L., Đorđević, V., Perić, V. \& Srebrić, M. 2013. Intercropping white (Lupinus albus) and Andean (Lupinus mutabilis) lupins with other annual cool season legumes for forage production. South African Journal of Botany 89: 296-300.

Moore, K.J. \& Jung, H.J.G. 2001. Lignin and fiber digestion. Journal of Range Management 54: 420-427.

Redfearn, D.D., Buxton, D.R. \& Devine, T.E. 1999. Sorghum intercropping effects on yield, morphology and quality of forage soybean. Crop Science 39: 1380-1384.

Zorić, L., Merkulov L, Luković J, Boža P. \& Krstić, B. 2011. Evaluation of forage quality of Lathyrus L. species based on histological characteristics. Acta Agronomica Hungarica 59: 47-55.

Zorić, L., Krstić, Đ., Ćupina, B., Mikić, A., Antanasović, S., Luković, J. \& Merkulov, L., 2012. The effect of field pea (Pisum sativum L.) as companion crop on leaf histological parameters of lucerne (Medicago sativa L.). Australian Journal of Crop Science 6: 430-435.

Zorić, L., Mikić, A., Ćupina, B., Luković, J., Krstić, Đ. \& Antanasović, S. 2014. Digestibility-related histological attributes of vegetative organs of barrel medic (Medicago truncatula Gaertn.) cultivars. Zemdirbyste-Agriculture 101: 257-264. 